\title{
Factors Affecting the Profitability of Insurance Companies in Albania
}

\author{
Assoc. Prof. Dr. Dorina Kripa \\ University of Tirana \\ Faculty of Economy \\ dorinakripa@feut.edu.al \\ Msc. Dorina Ajasllari \\ Deloitte Albania \\ dorina.ajasllari@gmail.com
}

\begin{abstract}
Good performance of a company determines the position of the company in its market and the growth and consolidation of the market, giving as result the development of the economy as a whole. The importance of this topic further enhanced when dealing with insurance companies because: 1) insurance companies' transfers risk in the economy 2) provide a mechanism to promote savings 3) promote investment activities. The growing importance of insurance companies in Albania and the importance of profitability as one of the key performance metrics of a company are the reasons why we decide to write this paper. The variation of profits between insurance companies over the years, within a country, leads to believe that internal factors play a major role in determining profitability. We have taken under study the impact of growth rate, liabilities, liquidity, fixed assets, volume of capital and company size on the profitability of insurance companies. The methodology used is based on quantitative methods and the data are provided by reliable sources such as annual reports of insurance companies', FSA ${ }^{1}$ reports and $\mathrm{NRC}^{2}$. We have taken under study 7 companies, including non-life and life insurance companies, from 20082013. The results of the paper show that factors such as growth rate, liabilities, liquidity and fixed assets are the main factors affecting the profitability of insurers, where the growth rate is positively associated with profitability, while liabilities, liquidity and fixed assets are negatively correlated. Company size and the volume of capital are positively correlated with the profitability of insurance companies', but their impact is statistically insignificant.
\end{abstract}

Keywords: Insurance, profitability, correlation

\section{Introduction}

It is necessary that insurance companies operate with profitability, so that the whole system can get the required development, taking into consideration the structure of the financial system in our country and the challenges faced by the insurance companies during the process of the development and consolidation of the financial nonbank system. Measuring the financial performance of the insurance market and the factors affecting its performance is a very interesting topic, theoretically and practically, to financial researches and to insurers. Profitability is one of the most important objectives of financial management, since one of the main tasks and goals of financial management is to increase shareholders wealth. At this point profitability is one of the main determinants of the performance of a company (Malik, 2011) 
Which are the factors affecting the profitability of the insurance market in Albania is the main question of this paper. Factors, which might affect the profitability of insurance companies, can be internal or external factors. This paper will focus on the impact of internal factors in the profitability of the insurance market, in order to try to determinate how factors depending upon insurance companies' decision affect their own profitability.

The second question, which will be raised in this paper, is how these factors affect the profitability of companies operating in the insurance market. The answer to this question cannot be given only through logical reasoning, but it requires a quantitative assessment by building a suitable model for this purpose. Finding reasonable answers to these questions is the focus of this paper. The answer to these questions and arguments to these answers together with the recommendations in this paper are intended to provide a clear framework of factors affecting the profitability of insurance companies.

\section{LITERATURE REVIEW}

\section{The role and the importance of insurance companies in the economy}

Recent research (Naveed, Zulfqar, \& Ahmad, 2011) have shown that the efficiency of financial intermediaries and risk transfer, may affect economic growth, while at the same time the lack of their solvability lead to systemic crisis, which bring adverse consequences for the whole economy. In this way, we can say that today's business world would be unstable, without financial institutions like insurance companies. That because on one hand, it is a normal phenomenon that some business units are surplus and some are in deficit and on the other hand, businesses do not have the capacity to assume all risks with which they face in the uncertain environment in which they operate.

Renbao Chen (Chen \& Wong, 2004) stated that high profits provide both the tools (bigger availability of funds), and the incentive for new investment (higher rate of return). Insurance companies have a dual responsibility, they must be profitable in order to be able to make new investments and they must be profitable in order to have the necessary solvability to convert other parts of the economy in previous state after the occurrence of damage.

\section{Factors affecting the profitability of insurance companies}

The variation of profits between insurance companies over the years, within a country, leads to believe that internal factors or specific factors of a firm play a major role in determining profitability. Authors like Sylwester Kozak in Poland (2011), Jay Angoff Roger Brown in the United States (2007), Al-Shami in UAE (2013), Swiss Re in Egypt (2008), etc. have studied the factors that influence profitability of non-life insurance company. Other authors like Adams, Hardwick of Zou in the UK (2008), Sandra Liang in Canada (2007), Wright in United States (1992) etc. have studied the factors affecting the profitability of life insurance companies. Most of these researchers, as for life insurance companies, as well as for non-life insurance company, focus on internal factors, where most used factors are the company age, company size, liabilities ratio, the volume of capital, fixed assets and liquidity ratio.

\section{The company size}

The company size can be expressed by many variables such as number of employees, number of branches, or total assets. Most researchers of the field use total assets to express the size of the company (Omondi \& Muturi, 2013); (Burca \& Batrinca, 2014); (Al-Shami, 2013); (Swiss Re, 2008); (Çekrezi, 2015); (Malik, 2011). The size of the company is considered as an influential factor because it shows that larger companies are better positioned in the market, operate with economies of scale, and thus enjoy higher benefits (Flamini, McDonald, \& Schumacher, 2015). Most studies conclude that there is a statistically significant positive correlation between the size of the company and its profitability, expressed by ROA (Swiss Re, 2008); (Malik, 2011); (Al-Shami, 2013). However, there are discussions about the optimal size of the company, which positively affects profitability. A growth in assets that extends an optimal ratio may have negative effects, due to increased bureaucracy (Yuqi, 2007) 


\section{Liquidity}

Liquidity for insurance companies shows the ability of insurers to pay current liabilities, which have the nature of operating expenses or payment of compensation in case of damage. For the insurer primary sources of liquidity are cash flow from net premiums, investment returns and liquidation of assets (Chen \& Wong, 2004). Most studies in this field treat liquidity as a factor affecting profitability, representing it by the current ratio (current assets / current liabilities). Regarding the relationship between liquidity and profitability of insurance companies, the results of different studies have been different. Some studies have concluded that there is a statistically insignificant link between liquidity and profitability for insurance companies (Naveed, Zulfqar, \& Ahmad, 2011) while other studies suggest that there are statistically significant negative links between liquidity and profitability of the insurer (Chen \& Wong, 2004).

\section{Liabilities}

Total liabilities are the sum of borrowed funds, used to finance the operation of a company. Researchers use ratio of liabilities to equity, to express this factor in analyzing the impact of liabilities on the profitability of insurance companies. Taking into account the effect of financial leverage, i.e. the use of debt to increase benefits, we must assume a positive relationship between liabilities and profitability. Companies driven to the use of liabilities due to tax incentives. Theories of optimal capital structures indicate that profitability increases as the level of debts increase to the optimal ratio and then falls if the debts continue to grow beyond this point. Increasing debts beyond a certain point, increase company risks and depreciate company value (Chen \& Wong, 2004). However, studies related to this topic (Omondi \& Muturi, 2013); (Burca \& Batrinca, 2014); (Chen \& Wong, 2004); (Malik, 2011) show that there is a statistically significant negative relation between liabilities and profitability of insurance companies. Titman and Wessels (1988) concluded that there was a statistically significant negative relation between the profitability of insurance companies in the US and the level of liabilities. We explained this conclusion by the fact that the theories of capital structure argue that insurance companies with high rates of liabilities have lower ROA, but higher ROE (Harrington, 2005)

\section{The volume of capital}

The capital of a company is expressed by the basic accounting equation as the difference between total assets with total liabilities. In studies related to factors affecting the profitability of insurance companies, the size of capital as a factor is represented by the ratio of shareholder equity to total assets, but this factor can be expressed by the carrying amount of capital insurance companies. These studies have shown that there is a statistically significant positive relation between the volume of capital insurance companies with their profitability, expressed by ROA (Al-Shami, 2013); (Malik, 2011).

\section{Fixed assets}

Fixed assets are represented by the ratio between fixed assets to total assets. Results of various studies on the impact of fixed assets in the profitability of insurance companies have been contradictory. Hifza Malik (2011) in his study of the factors affecting the profitability of insurance companies in Pakistan in 2011 shows that there is a statistically significant relationship between fixed assets and profitability of companies. He argues that due to the fact that the greater the weight of fixed assets in total assets, the greater is the insurance company, profitability will be even greater. However, a study conducted in the UK by Yuqi Li (2007) shows that there is no statistically significant relationship between fixed assets and profitability of insurance companies.

\section{The growth rate of the company.}

The growth rate for companies are generally expressed through the change in percentage of total assets of the company from year to year. In particular, for insurance companies growth rate expresses the percentage change in the total amounts of signed premiums from insurance companies. Studies related to these field show that there is a statistically significant positive correlation between the growth rate of the company and its profitability (Malik, 2011); (Yuqi, 2007); (Curak, Pepur, \& Poposki, 2011). It is also argued about the fact that a company always has to increase its resources to have a better performance, and consequently to be more profitable. However, the relationship between the growth rate of the company and its profitability may not be positive, as it is expected to be, because in some cases, a greater growth rate could expose an insurance company to a higher risk and that means that the company needs to increase its technical reserves (Burca \& Batrinca, 2014). 
Factors analysis and results

In this section, we present the analysis of factors affecting the profitability of insurance companies in Albania. These factors are subject to descriptive and correlation analysis. The conducted tests and their results are shown below.

\section{Descriptive analysis}

The following table shows descriptive statistics for the factors affecting the profitability of insurance companies, as well as for the profitability itself, represented by ROA.

Table 1: Descriptive analysis

\begin{tabular}{|c|c|c|c|c|c|c|c|}
\hline & Fixed assets & Liabilities & $\begin{array}{l}\text { Company } \\
\text { size }\end{array}$ & $\begin{array}{l}\text { Volume of } \\
\text { capital }\end{array}$ & Liquidity & Growth rate & ROA \\
\hline Average & 0.125827 & 1.305064 & 21.57140 & 20.78488 & 6.337284 & 0.135458 & -0.002638 \\
\hline Median & 0.123355 & 1.132017 & 21.32095 & 20.46779 & 5.662618 & 0.133821 & 0.020224 \\
\hline Max & 0.412115 & 3.462019 & 23.06227 & 22.02148 & 27.82843 & 0.743296 & 0.081380 \\
\hline Min & 0.022285 & 0.353759 & 20.28591 & 19.80254 & 0.440913 & -0.173673 & -0.500410 \\
\hline $\begin{array}{l}\text { Standard } \\
\text { Deviation }\end{array}$ & 0.099577 & 0.789245 & 0.884033 & 0.811577 & 6.530994 & 0.184907 & 0.106779 \\
\hline $\begin{array}{l}\text { Number of } \\
\text { observatio } \\
\text { ns }\end{array}$ & 29 & 29 & 29 & 29 & 29 & 22 & 28 \\
\hline
\end{tabular}

Source: Generated from e-Views7

Over the past 5 years, the average rate of the profitability of insurance companies in our country has been $(0.003 \%)$ with a standard deviation of $0.1 \%$. These data indicate that there is a moderate variation between the profitability of insurance companies taken into study. Table 1 also presents data on the average, median, maximum and minimum value and standard deviation. Overall fixed assets of 0.12 indicates that fixed assets comprise on average $12 \%$ of the total assets of insurance companies in the study. Standard deviation of 0.099 indicates that the variation of fixed assets between companies is moderate. The average 1.31 on liabilities shows that insurance companies' liabilities taken under study exceed by 1.31 times companies capital. Standard deviation of 0.78 indicates that there is significant variation among the companies surveyed for this factor. The factor company size has an average of 21.57 , which means that the total assets of the companies under consideration is on average 2.3 billion ALL and the standard deviation of 0.88 indicates that there is significant variation between companies in the study related to this factor. The volume of capital has an average of 20.78 , indicating that the average volume of insurance companies' capital is 1.06 billion ALL and the standard deviation of 0.81 indicates that this factor has a significant variation between companies in the study. Liquidity factor has an average of 6.34, which shows that short-term liabilities can be payed three times from current assets. Standard deviation of 6.53 indicates that there is a high variation among insurance companies to this factor. Growth rate has an average of 0.14 , which shows that the total premiums of the insurance companies taken under study have increased by $14 \%$ over the period 2008- 2014. Standard deviation of 0.18 shows that exist a sensitive variation among companies related to this factor.

\section{Correlation analysis}

Pearson correlation indicates the strength and the nature of the linear relationship between two variables. The correlation coefficient takes values between -1 and 1 . Below is shown the table of correlation between ROA (dependent factor) and independent factors 


\begin{tabular}{|l|l|l|l|l|l|l|l|}
\hline & $\begin{array}{l}\text { Fixed } \\
\text { assets }\end{array}$ & Liabilities & $\begin{array}{l}\text { Company } \\
\text { size }\end{array}$ & $\begin{array}{l}\text { Volume of } \\
\text { capital }\end{array}$ & Liquidity & Growth rate & ROA \\
\hline $\begin{array}{l}\text { Fixed } \\
\text { assets }\end{array}$ & 1.000000 & -0.265591 & -0.290740 & -0.201964 & -0.054042 & 0.493112 & -0.041875 \\
\hline Liabilities & -0.265591 & 1.000000 & 0.225706 & -0.086315 & -0.690919 & -0.453095 & -0.597070 \\
\hline $\begin{array}{l}\text { Company } \\
\text { size }\end{array}$ & -0.290740 & 0.225706 & 1.000000 & 0.950119 & -0.467403 & -0.151585 & 0.168505 \\
\hline $\begin{array}{l}\text { Volume of } \\
\text { capital }\end{array}$ & -0.201964 & -0.086315 & 0.950119 & 1.000000 & -0.245335 & -0.002019 & 0.352124 \\
\hline Liquidity & -0.054042 & -0.690919 & -0.467403 & -0.245335 & 1.000000 & 0.179353 & 0.239642 \\
\hline $\begin{array}{l}\text { Growth } \\
\text { rate }\end{array}$ & 0.493112 & -0.453095 & -0.151585 & 0.352124 & 0.179353 & 1.000000 & 0.383001 \\
\hline ROA & -0.041875 & -0.597070 & 0.168505 & 0.376661 & 0.239642 & 0.383001 & 1.000000 \\
\hline
\end{tabular}

Source: Generated from E-Views7

The table above shows that there is a negative correlation between liabilities and fixed assets with profitability and that there is a positive correlation between company size, volume of capital, growth rate and liquidity with profitability. From the table above, we realize that there is a strong negative relation between liabilities and ROA, where the correlation coefficients is respectively (0.59). The correlation coefficient of 0.38 indicates that there is a significant positive correlation between ROA and the growth rate. It is important to notice that there is a strong positive relationship between two of the independent variables such as company size and the volume of capital, showed by the correlation coefficient of 0.95 . This relationship can be explained by the fact that total assets represent the company size and the volume of capital is represented by the difference between total assets and total liabilities. A significant correlation between independent variables exist even between liquidity and growth rate $(0.45)$, as well as between liquidity and liabilities $(-0.47)$. Below, we will test the relationship between dependent variables and ROA, through student statistics (statistics $t$ ) and the level of significance (probability p)

\section{H1: There is a positive relationship between company size and the profitability of insurance companies in Albania}

Table 3: Correlation between company size and ROA

\begin{tabular}{|l|l|l|l|}
\hline Independent factor & Correlation coefficient & Statistics t & P \\
\hline Company size & 0.153604 & 0.695190 & 0.4949 \\
\hline
\end{tabular}

Source: Generated from E-Views7

From the table above we can see that there is a positive relationship between company size and profitability. Even though statistics $t$ and profitability $p$ show that this relationship is not significant

H2: There is a positive relationship between the volume of capital and the profitability of insurance companies in Albania.

Table 4: Correlation between the volume of capital and ROA

\begin{tabular}{|l|l|l|l|}
\hline Independent factor & Correlation coefficient & Statistics t & P \\
\hline Volume of capital & 0.376661 & 1.818400 & 0.0840 \\
\hline
\end{tabular}

Source: Generated from E-views7

The coefficient correlation shows that there is a strong, positive relationship between the volume of capital and profitability. With a reliability coefficient of 15\%, this relationship is statistically significant, which means that we accept hypotheses 2 as true.

\section{H3: There is a negative relationship between liabilities and profitability of insurance companies in Albania}


Table 5: Correlation between Liabilities and ROA

\begin{tabular}{|l|l|l|l|}
\hline Independent factor & Correlation coefficient & Statistics t & P \\
\hline Liabilities & -0.676004 & -4.102575 & 0.0006 \\
\hline
\end{tabular}

Source: Generated from E-views7

Statistics $t$ and probability $p$ show that there a significant negative relationship between liabilities and profitability. As a result, we accept hypotheses 3 to be true. The coefficient correlation of (0.597) shows that there is as strong relationship between these two factors.

\section{H4: There is a positive relationship between fixed assets and profitability of insurance companies in Albania.}

Table 6: Correlation between fixed assets and ROA

\begin{tabular}{|l|l|l|l|}
\hline Independent factor & Correlation coefficient & Statistics t & $\mathrm{P}$ \\
\hline Fixed assets & -0.180412 & -0.820286 & 0.4217 \\
& & & \\
\hline
\end{tabular}

Source: Generated from E-views7

Statistics $t$ and probability $p$ show that the relationship between fixed assets and the profitability of insurance companies is not statistically significant. We cannot accept hypotheses 4 .

H5: There is a negative relationship between liquidity and profitability of insurance companies in Albania

Table 7: Correlation between liquidity and ROA

\begin{tabular}{|l|l|l|l|}
\hline Independent factor & Correlation coefficient & Statistics t & P \\
\hline Liquidity & -0.505287 & -2.618588 & 0.0165 \\
& & & \\
\hline
\end{tabular}

Source: Generated from E-views7

The coefficient correlation of 0.24 shows that the relationship between liquidity and profitability is positive, but not significant. This result means that we cannot accept hypotheses 5.

\section{H6: There is a positive relationship between growth rate and profitability of insurance companies in Albania}

Table 8: Correlation between growth rate and ROA

\begin{tabular}{|l|l|l|l|}
\hline Independent factor & Correlation coefficient & Statistics t & P \\
\hline Growth rate & -0.693335 & -4.302831 & 0.0003 \\
\hline
\end{tabular}

Source: Generated from E-views7

The table above shows that the relationship between growth rate and ROA is positive and strong, with a correlation coefficient of 0.38 . Statistics $t$ and probability $p$ show that this positive relationship is statistically significant. We accept hypotheses 8 as true.

\section{Discussion of results}

Descriptive analysis showed that the average profitability of insurance companies surveyed for the period 2008- 2013 was $-0.3 \%$. Insurance companies in Albania operate with an negative average profitability, at a time where maximum profitability for the period does not go further than $8 \%$ and where the minimum profitability for the period was $-50 \%$, a very negative result. On the other hand, the standard deviation of 0.1 indicates that the variation in profitability among the Albanian insurance companies in the study is moderate, so we do not expect significant differences between their profitability. The main reason for this result is that the insurance market in Albania is still underdeveloped, modest and concentrated on compulsory insurance (Sharku \& Bajrami, 2008). The insurance market in our country still suffers from phenomena such 
as unfair competition, pricing below cost to artificially boost companies market share, the administrative costs for the legal process are too high, marketing abuses, which express their influence on the negative performance of insurers profitability (Petraj, 2013).

\section{Size company impact on profitability of insurance companies in Albania}

Correlation analysis showed that company size factor had a positive impact, however insignificant in the profitability of insurance companies in our country. Other international studies on the impact of company size on the profitability of companies in general have also reached the same result or outcome that the impact of the size of the company is negatively related to profitability (Niresh \& Velnampy, 2014); (Velnampy \& Nimalathasan, 2010). One explanation for this result is the fact that financial sector companies, which include insurance companies, are less affected by the size of the company in their profitability, compared to industrial companies. However, the conclusion reached by the study is consistent by the results reached by Çekrezi (2015)on the impact of company size on the profitability of insurance companies in Albania

\section{Volume of capital impact on profitability of insurance companies in Albania}

Correlation analysis showed that the volume of capital had a positive statistically significant impact on the profitability of insurance companies in our country. Regression analysis confirmed the positive nature of the relationship between the volume of capital and ROA, but it resulted in statistically irrelevant links. The early hypothesis of the paper was that the capital has a positive impact on the profitability of insurance companies, as a greater capital enables insurance companies to seize opportunities quickly and react quickly in case of loss. We can say that the impact of the volume of capital factor in the profitability of insurance companies could be subject to macroeconomic factors specific to each country, which are not considered in this study

\section{Liabilities impact on profitability of insurance companies in Albania}

The result of correlation analysis showed that there is a statistically significant negative relationship between liabilities and profitability of insurance companies in our country. Result is consistent with the hypothesis raised at the beginning of the paper. Correlation analysis showed that the relationship between liability and insurance companies in our country in the study was a strong negative correlation coefficient of -0.6. The findings coincide with the results of international studies about the impact factor in profitability liabilities of insurance companies as (Chen \& Wong, 2004); (Malik, 2011); (Burca \& Batrinca, 2014); (Onaolapo \& Kajola, 2010); (Titman \& Wessels, 1988).

\section{Fixed assets impact on profitability of insurance companies in Albania}

Correlation analysis showed that the link between fixed assets and profitability of insurance companies was a weak, with a correlation coefficient of (0.04), but negative. Regression analysis also showed that an increase in fixed assets variable brings a decline in the profitability of insurance companies. The result achieved rejects the hypothesis raised at the beginning of the paper. However, the above result is in accordance with the results achieved by Yuqi Li (Yuqi, 2007). The reason for this result can be explained by the fact that the increase in fixed assets beyond an optimal level does not affect positively the profitability of a company (Yuqi, 2007).

\section{Liquidity impact on profitability of insurance companies in Albania}

The result of regression analysis confirmed the hypothesis raised at the beginning of the paper, so there is a statistically significant negative correlation between the profitability of insurance companies in our country and their profitability. The reason for this result is explained by the fact that the greater is the current ratio (through which represented liquidity) the smaller is the profitability (Chen \& Wong, 2004), as funds held in the form of liquidity can be invested and ensure higher profitability (Chen \& Wong, 2004).

\section{Growth rate impact on profitability of insurance companies}

The result of correlation analysis showed that the impact of the growth rate of the insurance companies in their profitability is positive and statistically significant. This result agrees hypothesis raised at the beginning of the paper, where we 
assumed that there was a positive correlation between the growth rate and profitability of insurance companies. The result is explained that by the idea that by collecting more premiums insurance companies provide more funds to carry out investment, have more capacity to respond to complaints in case of damage, manage to increase their market share, which reflected positively on profitability. The above conclusion is also consistent with the conclusions reached by international scholars (Malik, 2011); (Yuqi, 2007); (Naveed, Zulfqar, \& Ahmad, 2011) about the impact of the rate of growth in the profitability of insurers.

\section{Recommendation}

In accordance with the results of the study carried out in this paper, we can give the following recommendations:

Albanian insurance companies operate with a negative average profitability. Taking in consideration the nature of influence of the above factors on the profitability of insurance companies it is recommended that:

- Insurance companies in our country should avoid the very high levels of debts, as they have a negative impact on their profitability. On the other hand, high levels of debts could lead to bankruptcy due to inability to pay these liabilities.

- The negative impact of liquidity on the profitability of insurance companies leads to the recommendation that the optimal level of liquidity holding is an important issue for financial decision-making insurance companies. They must find a balance between the need to keep funds in the form of liquidity to pay their short-term liabilities and those that may engage in investment.

- The growth rate of insurance companies, reflecting the change in the level of gross premiums from one year to another, has a positive impact on the profitability of insurance companies. However, the increase in premiums must be accompanied by investing capacity, providing suitable products for both businesses and individuals, education and advice to the public about the importance of insurance, whether mandatory or voluntary, and not through price competition between companies operating in the market.

- Fixed assets negative have a negatively impact on the profitability of insurance companies, so insurers should not hold high levels of fixed assets. Insurance companies, as if financial institutions do not need many fixed assets, so they should be prudent in relation to the level of fixed assets.

This paper took under study 6 internal variables to explain the profitability of insurance companies in our country. Including other variables external nature and would enrich the macroeconomic framework of the paper and will give a complete view of factors that affect the profitability of insurance companies, which operate in our country.

Further research

In a further study, we will discuss about the implications of the above mention factors in a multiple regression model with panel data, in order to determine the nature of influence of these factors on the profitability of insurance companies in Albania. The regression model helps on understanding how changes on independent factors, in our case growth rate, volume of capital, company size, liquidity, liabilities and fixed assets, affects profitability of insurance companies. This way, we can give suitable recommendation for the improvement of profitability of insurance companies in our country.

\section{References}

Adams, M., Hardwick, P., \& Zou, H. (2008). Reinsurance and Corporate Taxation in the. Journal of Banking and Finance.

Al-Shami, H. A. (2013, Korrik 24). Universiti Utara Malaysian Electronic Theses and Dissertation. Tratto il giorno Maj 13, 2015 da Universiti Utara Malaysian: etd.uum.edu

Angoff, J., \& Brown, R. (2007). An Analysis of the Profitability and Performance of the Michigan Auto Insurance Market . Michigan Auto Law.

Burca, M., \& Batrinca, G. (2014). The determinants of financial performance in the Romanian insurance market. International Journal of Academic Research in Accounting, Finance and Management Sciences. 
Çekrezi, A. (2015). DETERMINANTS OF FINANCIAL PERFORMANCE OF THE INSURANCE COMPANIES: A CASE OF ALBANIA. International Journal of Economics, Commerce and Management, Vol III, Issue 4.

Chen, R., \& Wong, K. A. (2004). The Determinants of Financial Health of Asian Insurance Companies. The Journal of Risk and Insurance, 469- 499.

Curak, M., Pepur, S., \& Poposki, K. (2011). Firm and Economic Factors and Performance: Croatian Composite Insurers. The Business Review Cambridge.

Flamini, V., McDonald, C., \& Schumacher, L. (2015). The Determinants of Commercial Bank Profitability in Sub-Saharan Africa . International Monetary Fund.

Harrington. (2005). The Effect of Competitive structure on the relationship between leverage and profitability.

Kozak, S. (2011). Consolidation and Efficiency of the Non-Life Insurance Sector in Poland. Electronic Journal of Polish Agricultural Universities, Vol 13.

Malik, H. (2011). DETERMINANTS OF INSURANCE COMPANIES PROFITABILITY:AN ANALYSIS OF INSURANCE SECTOR OF PAKISTAN. Academic Research International, Volume 1, Issue 3.

Naveed, A., Zulfqar, A., \& Ahmad, U. (2011). Determinants of Performance: A Case Of Life Insurance Sector of Pakistan. International Research Journal of Finance and Economics, Eurojournals Publishing, Inc.

Niresh, J. A., \& Velnampy, T. (2014, Mars 21). Firm Size and Profitability: A Study of Listed Manufacturing Firms in Sri Lanka. Tratto il giorno Maj 3, 2015 da Department of Accounting, Faculty of Management Studies \& Commerce, University of Jaffna, Sri Lanka : file:///C:/Users/Acer/Downloads/33483-120092-1-PB\%20(1).pdf

Omondi, M., \& Muturi, W. (2013). Factors affecting the financial performance of listed companies at the Nairobi Securities Exchange in Kenya. Research Journal of Finance and Accounting, 99-104.

Onaolapo, A., \& Kajola, S. (2010). Capital structure and firm performance: Evidence from Nigeria . European Journal of Economics, Finance and Administrative Sciences.

Petraj, I. (2013). INSURANCE MARKET IN ALBANIA. Dukagjini College.

Sandra, V., Lianga, \& Desheng, Z. (2007). Simultaneous analysis of production and investment performance of Canadian life and health insurance companies. Computers and Operations Research.

Sharku, G., \& Bajrami, E. (2008). THE IMPACT OF “INSURANCE CULTURE” IN DEVELOPMENT OF THE INSURANCE MARKET IN EMERGING ECONOMIES - case of Albania. Epoka.edu.al.

Swiss Re. (2008). Publications. Tratto il giorno Maj 23, 2015 da Insure Egypt: http://www.insureegypt.com/publications.html Titman, S., \& Wessels, R. (1988). The determinants of capital structure choice. Journal of Finance.

Velnampy, T., \& Nimalathasan, B. (2010, Prill). Firm Size on Profitability: A Comparative Study of Bank of Ceylon and Commercial Bank of Ceylon Ltd in Srilanka. Tratto il giorno Maj 10, 2015 da Academia.edu: https://www.academia.edu/2501577/Firm_Size_on_Profitability_A_Comparative_Study_of_Bank_of_Ceylon_and_Comm ercial_Bank_of_Ceylon_Ltd_in_Srilanka

Wright, K. (1992). The Life Insurance industry in the United States an analysis of economic and regulatory issues. Country Economics Department the world Bank policy research working paper.

Yuqi, L. (2007). Determinants of Banks Profitability and Its Implication on Risk Management Practices: Panel Evidence from the UK. University of Nottingham. 